\title{
Artistic Culture and Ethnicity: Maintaining the Present-day Buryat Ethnosphere
}

\author{
Darima D. Amogolonova* \\ Institute for Mongolian, Buddhist \\ and Tibetan Studies SB RAS \\ 6 Sakhyanovoi Str., Ulan-Ude, 670047, Russia
}

Received 20.02.2018, received in revised form 27.08.2018, accepted 11.09.2018

The paper proposes a new look at the phenomenon of ethnosphere on materials of post-soviet Buryatia. Though depoliticized for almost two decades, Buryat ethnicity remains one of the principal social identities that now manifests not in the political but in the cultural space. The author argues that having lost their political pathos, nowadays the ideas of ethnonational revival and ethnic consolidation that were topical at the period of ethnic mobilization (from late 1980s to 2000) found their expression and embodiment in the artistic culture. Various fields of creative work - painting, prose and poetry, theatre, music, cinema-are looking for the ways, which consistently connect the ethnic cultural traditions with modern artistic forms. The plots vary but correspond to the topics of the Buryat ideology - Great Past and national heroes both historical and folklore, ethnic spirituality and religiosity, necessity to keep and develop the ethnic language and economy, and maintaining ties with Mongolian community.

Keywords: Buryats, artistic culture, depoliticization, cultural ethnosphere, historical memory, Buryat ideology, identity, cultural heritage.

The research has been carried out in the framework of the Project " $A$ comprehensive study of the religious, philosophical, historical, cultural, and socio-political aspects of Buddhism in the traditional and contemporary contexts of Russia and the countries of Central and East Asia".

Research area: culturology.

Citation: Amogolonova, D.D. (2018). Artistic culture and ethnicity: maintaining the present-day Buryat ethnosphere. J. Sib. Fed. Univ. Humanit. soc. sci., 11(9), 1374-1385. DOI: 10.17516/1997-1370-0310.

\section{Introduction}

The Buryat ideology appeared at the turn of the $19^{\text {th }}$ and $20^{\text {th }}$ centuries and aimed at avoiding Christianization and russification, which threatened the Buryats as a

(C) Siberian Federal University. All rights reserved

* Corresponding author E-mail address: amog@inbox.ru

This work is licensed under a Creative Commons Attribution-NonCommercial 4.0 International License (CC BY-NC 4.0). 
unique ethnic community possessing culture and traditions of its own. The revival of the Buryat ideology began in the years of perestroika in the USSR when new Buryat leaders adopted slogans of the pre-revolutionary era and applied them to modern conditions. Russian civic identity was not questioned; nevertheless, the leaders put forward the ideas of ethnic consolidation on the basis of common historical and cultural memory and religious values. The aim was similar to the previous one: to preserve the Buryat community and its heritage. With the passage of time and change in the Russian political climate, the Buryat ideology has depoliticized but ideas about cementing values still take strong positions in the public consciousness and find reflection in the artistic sphere. The feedback between the ideology and culture simultaneously exists between art works and ordinary consumers of culture. Constructed on the idea of 'soil and blood', ethnosphere is presenting an ethnic cosmology with its specific markers and signs. Thus, this or that degree of acquaintance with ethnic culture provides preferences in social identification by means of reinforcing in the public consciousness not always formulated, but understandable ideas of ethnocultural solidarity.

\section{Materials and Methods}

In the late 1980s, the new Buryat ethno-cultural revival was headed by the representatives of the humanities (historian Sh. Chimitdorzhiev, historian G. Sanzhiev, ethnographer T. Mikhailov, etc.) who were inspired by the ideas formulated by the leaders of the pre-revolutionary era and the first decade of Soviet history - Ts. Zhamtsarano, M. Bogdanov, A. Dorzhiev, E.-D. Rinchino, and B. Baradin who proposed the concepts, often opposing, how they saw the future of the Buryats in the conditions of departure from the traditional society and inclusion in new socio-political and economic conditions. The 'new' intellectual elites began their activities when the fears expressed by the 'old' leaders have already implemented, i.e. many components and features of the authentic Buryat society were lost forever, the Soviet regime successfully suppressed religion, and when urbanization and Soviet education as a characteristic of modernization led to cultural (in particular, language) russification. To return the Buryat national spirit to the public consciousness, the new leaders proposed various projects: revival of nomadic stock breeding, use of religious revival initiated by the Russian authorities for restoring true Buddhist and Shamanist religiosity that would promote morality and ethnic rallying, reestablishment of ties with Mongolia in the cultural and economic spheres, revival of folk traditions (folklore, festivals, and applied arts). The workers of literature and arts enthusiastically supported the processes 
of ethno-cultural revival. It may seem that they are performing a 'social order' but this is a superficial view. In fact, this is a question of constructing a new ethnic reality, in which the idea of the ethnonational consolidation plays a dominant role. In this sense, the artistic creativity for the most part is the process of comprehension of the Buryat historical and cultural heritage, mentality and way of life while talent, creative vision, style, and personal preferences provide variety of artistic topics. Therefore, the main materials of the study are the samples of artistic creativity proposed by writers and poets, artists and musicians, dancers, theatre workers and cinematographers.

The methodological basis of the study is the concept of social functions of culture formulated by E. Durkheim and developed by Yu. Lotman. Moreover, the proposed concept of the 'Buryat ethnosphere' I derived from Lotman's semiosphere in its essential meaning as communication space that possesses numerous social functions, in particular, educational and training (Lotman, 2005: 205-229). The ethnosphere represents both cultural experience and a systematized totality of signs and symbols representing a special language. In our case, this is the discourse of identity: purposefully constructed and educated in the public consciousness, the discourse exists due to need in belonging to the group and its values.

\section{Results}

The turbulent period of ethno-nationalist mobilization in Russia (from late 1980-es to 2000) gave place to depoliticization of ethnicity with the simultaneous development of various aspects of the ethnic culture, which together constitute the basis for the ethnocultural space - ethnosphere. These processes are characteristic for most if not all ethnic groups and Buryats among them. The Buryat discourse at the period of burst of ethnicity was characterized by the inseparability of political and cultural aspects, later it completely lost nationalist pathos and the political issues disappeared without a trace, in particular, the discussion on the right to self-determination, merging ethnic Buryatia i.e. three regions of Buryat compact accommodation (Buryatia, Ust-Orda Buryat Autonomous District and Aginsky Buryat Autonomous District) as one political subject of the Russian Federation, the return of the politonym Buryat-Mongols and even reunification with Mongolia. Let us note that ordinary carriers of Buryat ethnicity showed some interest in political topics but did not participate in political actions. Quite another matter was culture. The problems of cultural revival, including religion, the Buryat language, folklore and literature, traditional forms of economic activity (nomadic stock-breeding) and, in general, the preservation of Buryat village and rural 
economy, were and still are remaining the important aspects of the sociocultural landscape. Historical memory of ancestors and national heroes, real and mythological, become the topics of artistic creativity and provide basis for festivals and feasts; they are included in educational programs. In these ways, the identity of the ethnic group is being preserved and developed.

While cultural workers of Buryatia (not necessarily Buryats) are actively working in the field of artistic creativity based on traditional values, they are guided by the requirements of modernity in style and forms of expression. The Buryat cultural life was coordinated by the interregional public movement 'The All-Buryat Cultural Development Association' (VARK), which in 2016 celebrated the $25^{\text {th }}$ anniversary of existence. Ts.-D.E. Dorzhiev, the speaker of the People's Hural (Parliament) when addressing to the VARK Congress in 2016 once again defined the purpose of the organization as promoting spiritual unity and consolidation of the Buryats living in different parts of the world, and formulated the organization's tasks as preserving ethnic identity by supporting the Buryat language, reviving traditions and customs, because 'only in this way can we survive as the Buryat ethnos' (Vseburiatskaia, 2016).

In modern Buryat art, the variety of subjects and means of artistic expression fully corresponds to the algorithm of returning to the roots and overcoming the socialist facelessness, predetermination and averaging, which the famous artist Alla Tsibikova in the late 1980s (in connection with the revival of traditional painting) characterized in the following words: 'Of course, everything and everywhere is subjected to some kind of standardization, and belated jerks to the lost space of the cult art look like another retro and motley flap from once luxurious clothes in inept imitating hands. But still, in these attempts one can see in most cases sincere desire to stretch the thread of blood relationship with the great culture of the East. $<\ldots .>$. We are almost cosmopolitans. $<\ldots>$ I got a feeling of nationality very late $<$...> . Apparently, the 'connection of times' broke and the flow of national art shrunk to the stream of applied art. They (the Mongols D.A.) preserved pulsating ancient blood while we have only water' (Koreniako, 2003: 91-92).

The rejection of socialist standards by means of re-ethnization of contemporary Buryat artistic creativity is due to the interest on the side of artists, sculptors, stage directors, and musicians to national themes related to cultural and historical memory. At the same time, the artistic discourse, on the one hand, is based on the values that are significant for the ethnic group, and on the other, it contributes to strengthening unified picture of the Buryat ethnosphere, in which there are constants representing the matrix 
of artistic creativity: the grandeur of history and bitter national traumas, cultural achievements (folklore and applied art), high spirituality, expressed in devotion to the Buddhist religion and shamanic rituality.

Describing the ethnosphere - a system of signs - through a variety of images, the artistic creativity enriches them with symbolic meanings embedded in recognizable signs. Thus, culture fulfills a social function, of which Yuri Lotman wrote, 'the works of art are extremely economical, capacious, and profitable ways for storing and transmitting information. Some of their very valuable properties are unique and do not occur in other capacitors and transmitters of information, created so far by the humanity' (Lotman, 2001: 9-10). The advantage of artistic creativity lies in its democracy and accessibility, and the desire to get to know it is conditioned by the general cultural mood and social need to fit the ethnic community. It can be said, the symbols that are supposedly equally understood by the carriers of culture transmit the socially significant coded information, which serves both aesthetic and various integrative and educational purposes. Thus, it can be said that works of art are both a fragment of the ethnosphere, and a way of describing it, and even in general they are the form (or one of the forms) of its existence.

The process of constructing the post soviet ethnic identity includes the embodiment of ideologems that are assimilated and appropriated by the public consciousness, and the diversity of their artistic realization is determined by the talent, manner and goals of the author. And so for the artist, the plot is only the starting point of self-expression, whereas the artistic vision and aesthetic views of the author play in the creative work a more important role. The exception is modern Buddhist iconographic painting, in which the canon is immutable and perception requires knowledge of Buddhist mythology.

Special knowledge on the Buddhist canon including icon painting is acquired by the students of the school-studio Buryad Zurag (Buryat traditional painting) founded by the famous artist Dashi-Nima Dugarov. The students are taught to paint tankas (religious paintings) with mineral paints. Journalist Yuri Khoroshikh said about D.N. Dugarov's role in the Buryat ethnocultural revival the following: 'He was an artist, philosopher, thinker, fighter, ideologist, friend and son of his land' (Khoroshikh, 2008: 14).

Buddhist stories illustrating the revival of the Buddhist tradition in Buryatia are also present in secular painting drawn in the traditional style. The artist Lubsan Dorzhiev uses the iconographic style in portraiture (portrait of Aghvan Dorzhiev) and the style of zurag in the pictorial art: 'The Taming of the Tiger by Dugar Zaisan', 
'Luu' (dragon), 'Mataray Tolgoi' (Makara monster). Traditional Buryat ornamentation is used by the artist to depict clouds, mountains and land in the picture 'Domog' (green foal).

Ethnic history and culture represent an inexhaustible source of stories, and images of real characters intersperse with mythological (epic) heroes. Chinggis Khan and his time were the main themes of the art works during the period of the colossal interest on the side of Buryats to the common Mongol history, which, in addition, was induced by a landmark event on a world scale - the $800^{\text {th }}$ anniversary of the Mongol empire (2006). The epic hero Geser attracts even more and still unrelenting interest; this is expressed in painting and sculpture (Alexander Mironov) and in music: the composer Anatoly Andreev created a three-act opera 'Geser' that was staged at the Buryat Opera House.

At the same time, critics do not always agree when artists explicitly subordinate their own creative vision and manner to the pictorial traditions, which impart them excessive solemnity and 'a certain cliché in creating the image of the hero' (Batorova, 2001: 10).

Dashi Namdakov, the most famous Buryat metal sculptor, shows quite a different approach to creativity. His works combine European plastic classics and Buryat plots. Not following the canon, Dashi Namdakov embodies folklore, Buddhist and shamanic ideas, zoomorphic ideas about the elements and time in the dynamic figures of real and fantastic characters ('Tsar-Bird', 'Mode's Horse', 'Zaan' (elephant), 'Raven', 'Elemental Force', 'Buha-Nayon' (bull-lord and totem progenitor of the pre-Baikal Buryats), 'Remembering the future').

The sculptor Bair Sundupov bases his work on the Buryat and Central Asian art traditions, at the same time modern style is consistent with the concepts of Buddhist religion and philosophy, with the battle history and nomadic everyday life of the ancestors (sculptures 'The Death of the Nomad', 'The Transformation of Yamaraja', 'Sükhbaatar', 'Toshaangui' (Passion), 'Hoohon Shanar'(Allegory), 'Khan Herdig' (Khan Garuda), 'Tahil' (Offering to the deities)'.

Reinterpreted and modernized plots of the Buryat national folklore formed the basis for a number of theatrical productions. In the play 'The Wedding Circle, or the Uleyskie Girls' (authors Erzhena and Sayan Zhambalovs, director Dzhemma Batorova), staged in the Buryat Drama Theatre, the modern wedding is intertwined with mystical plots of the West Buryat legends. When evaluating the artistic merits and innovative means used to embody the idea of the performance, the theatrical critic A. Politov noted that epic legends and folklore that are kept in the collective memory give the 
opportunity to perceive cultural heritage as a part of modern life and as philosophy of the ethnic group (Politov, 2000: 8).

The Buryat fairy tales formed the basis for the performance 'The Singing Arrow' (the puppet theatre 'Ul'ger', director Erdeni Zhaltsanov). The action begins as it was accepted in the performances of the old times. An uligershin (storyteller) comes to the ulus and tells the adults and children the legend of the brave old warrior Meelbator who alone resisted the enemy horde led by brutal Eelen-bator. The performance presents folklore motives dynamically and with humour and, most importantly, is quite understandable to the today young spectator. Moreover, the staging, play and text brightness of the performance helped the performance to be warmly received not only in Ulan-Ude but also in Moscow where it become the laureate of the Golden Mask Award (2006) and was included in the repertoire of the Moscow Puppet Theatre.

The folklore and mythological traditions of the Mongolian-speaking peoples transmitted in modern choreography and musical accompaniment are the basis for the play-elements 'Ugaym Sulde' (the spirit of ancestors) staged by the 'Baikal' theatre. The creators of the play see the goal of their work in the reconstruction of the worldview of the nomadic ancestors so that the viewer could 'feel the breath of past time, study the history of our ancestors and discover a new dimension to life' (Mudraia sila, 2005: 20). The play received widespread approval in Russia and in many other countries. Created in 2005, it remains to this day the most spectacular, attractive and voluminous work of the theatrical art of Buryatia.

As an element of the Buryat ethnosphere, artistic revival appeals not only to the feeling of kinship with tradition; when opening the ethnic values, the art fulfils the educational function of culture since many Buryats, especially city dwellers, have superficial ideas about traditional beliefs - Buddhism and shamanism (and their mythology). An example is the dramatized concert 'Ode to the Swan-Mother' staged at the dance theatre 'Badma Seseg' (art director Dandar Badluev), which represents the reconstruction of the shamanic rite: travel of the shaman to the lower, middle and upper worlds. It is implied that along with artistic tasks the performance has to be reliable from the point of religious traditions and give a generalized shamanic cult action. In an interview, Dandar Badluev said that the work on the play was complicated and demanded new knowledge on Buryat ethnography, for this he previously 'was flipping through hundreds of magazines and books, went on folklore expeditions, met the venerable old men, often visited museums to study in detail the cut of traditional Buryat clothes of different localities including clothing of nomadic tribes' (Gonchikova, 
2002: 8). The dance in the play depicts the shamanic ritual quite veraciously: 'The feast in honour of the Swan-Mother continues to be completed by noon. Together with the bright rays, the Hori-Buryats and Hongodors will say goodbye to their totem until the next tailgan. But first they will bring white hadak (a ritual scarf. - D.A.) to the Swan-Mother and each of them will carry to his home a piece of sacred charcoal to strengthen his hearth' (Gonchikova, 2002: 8).

Note that the traditions of Buryat shamanism as the indigenous belief that in Buryatia it is older than Buddhism (which came to Transbaikalia from Mongolia in the beginning of the $17^{\text {th }}$ century), occupy a significant place in the art work. The revival of ethnocultural memory was the focus of the exhibition of contemporary artists 'Shamanic Path' at the Museum of History of Buryatia. The exposition represented visual images of the shamanic worldview and rituals: the images of the patron-spirits, clan obo (places of worship) and shamans at rites (Chingis Mandaganov's 'Shaman', 'The Rite', and 'Hunter'; Eugene Bolsoboev's 'The Ritual' and 'Taiga dweller') are close to the visual and artistic embodiment of shamanic cosmology; for example, Eugene Bolsoboev's picture 'Zambi Tib' (a journey through the worlds) depicts a three-partial vertical division of space centered on the shaman who runs through all three levels on a horse.

The educative and training function of culture is presented even more clearly in the book for children 'The Diamond Book about the Buryats' written and illustrated by the painter Viktoria Alaguyeva: the drawing that shows a vertical three-part shamanic cosmology is called to demonstrate the structure of the universe to the children. Explaining the images, the author writes: 'The upper world is Heaven. The Lord is Sun. The middle world is the Earth. The Lady is Etugen. The lower world is the Underwater and the Underground Kingdoms. The Lord is Usa Loson' (Alagueva, 2007: 64, 76). The book is noteworthy for witnessing in artistic forms to a long-standing religious syncretism in Buryatia that implies a non-contradictory mix of Buddhist, shamanic and Christian themes. Describing the Buryat traditional cosmology, V. Alaguyeva depicts the spirits and masters of the localities (Lord of Baikal, Mistress of the Angara) alongside with the Buddha ('The Buddha always looks after his children sending them his love') and the Bodhisattvas, and at the same time explains that the Archangels are 'Our Heavenly Fathers', of them Archangel Michael is specially marked as 'equal to God' and 'Vajradhara' (Alagueva, 2007: 81) (i.e. the original Buddha, the personification of Dharmakaya).

Chinggis Khan who in the discourse of the Buryat ethnocultural revival takes the central place of the national hero also became a notable topic in the artistic creativity. 
For example, in the Yalbak Khalbay's book 'Chinggis Khan the Genius' ChinggisKhan is portrayed as a great military leader, humanist, and most eminent statesman and simultaneously as a seer and peacemaker. Proving the genius of Chinggis-Khan, the author resorts to the style of a solemn prosaic ode, which in a stating manner asserts that the Mongols of the Chinggis Khan epoch were the most advanced people of the world because they were guided by fair laws the Yasa, created diplomacy, possessed morality and culture that conquered people: 'Human history does not know more humane conquerors and rulers-outlanders' (Halbai, 2001: 267-269, 283).

Chinggis Khan's image in the theatrical art is accompanied by the same dignified and solemn tone. The play 'Chinggis Khan' (author of the play Bulat Gavrilov) staged in the Buryat drama theatre relies on the 'Secret History' but focuses on philosophical and ethical issues that are more significant for contemporaries: 'Is it possible that the one who has suffered such a mockery of himself will not try to rid his relatives, his kind and tribe, and the whole world of such arbitrariness?' (Vasil'eva, 2001: 12).

In the triptych 'From the Depth of Ages' ('Mother of Chinggis Khan', 'Chinggis Khan', and 'Chinggis Khan in Central Asia') the painter Innokentii Nalabardin draw a grandiose half-length portrait of Chinggis Khan over countless Mongol warriors in the central picture. The lofty epic representation of the past revives the pride for ancestors and simultaneously symbolizes the complete rejection of Soviet interpretations of the era of the Mongol invasions. The same meaning is present in the feature film about the times of the Mongolian empire 'The First Nuker of Chinggis Khan' based on Alexei Gatapov's novel. The film tells the story how Temujin first met Bo'orchu who later became the khan's faithful companion and friend; Buryat viewers across the ethnic Buryatia watched the film with great enthusiasm.

The theme of complicity to the history of the native land is expressed through poetic images of cultural memory in the Buryat poetry represented in the creativity of Bair Dugarov, Galina Radnaeva, and Esugei Synduev.

The verses deal with variety of topics but the main themes are recognizable and closely related to the discourse of ethnic revival: the native land, the great past, the nomadic ancestors, Chinggis Khan and his time, and the epic hero Geser. In discussing the problems of national revival, an important place was given to preserving the Buryat language and attempts to avoid linguistic russification; in art creativity, this theme has found wide reflection. The poet Bair Dugarov asks for forgiveness from the Buryat language for his Russian-language work ('the language of the fathers, I'm sorry for the dumbness'), and Esugei Sinduev hopes that the situation can be changed and 
calls on the Buryats to return to the ethnic language: 'Hey, Russian-speaking Buryat, / Eurasian splice! / Where is your / guttural, stentorian, / And song language? / <... We will return it, / To confess love / you managed in it. / So that you were bilingual, / In order you don't wean/ To glorify the guttural, stentorian, / And song language' (Synduev, 2005: 14).

\section{Conclusion}

Ethnic ideology and artistic culture in Buryatia have established a strong feedback with each other basing on the search, definition and translation of ethnic identity. Literature and arts as a part of ethnocultural revival, on the one hand, rely on tradition, and, on the other hand, are conditioned by the modern state of public consciousness; and this provides them with popularity and support in the most diverse layers of the population, both Buryat and non-Buryat. Artistic creativity represents visible and bright symbols that prove the existence of the ethnosphere that is a systematized set of socialized signs and codes. Ethnic values were the basis for political slogans and programmes of the Buryat revival at various stages of history beginning from the end of the $19^{\text {th }}$ century. And at present ethnicity is depoliticized, and the artistic process fully meets the demands in the field of expression of ethnic feelings, moods and needs. Moreover, pieces of art act as distinctive features and in this quality promote formulating the intercultural and multiethnic values and regional cultural text.

\section{References}

Alagueva, V.P. (2007). Almaznaia kniga o buriatakh [The Diamond Book about Buryats]. Ulan-Ude: Izd-vo OAO "Respublikanskaia tipografiia". 96 p.

Batorova, E. (2001). Vse poznaetsia $\mathrm{v}$ sravnenii [Everything is learned in comparison]. In Buryatia, May 16, 10.

Gonchikova, N. (2002). "Badma Seseg" poet odu Materi-Lebedi ["Badma Seseg" is singing an ode to Mother-Swan]. In Buryatia, January 24, 8.

Khalbai, Ia. (2001). Chingis-han - genii [Chinggis khan the genius]. Ulan-Ude: Izdatel'stvo OAO “Respublikanskaia tipografiia”, 296 p.

Khoroshikh, Iu. (2008). Kisti i strely [Brushes and arrows]. In Pravda Buriatii, May 15, 14.

Koreniako, V.A. (2003). Al'bina Tsybikova - khudozhnik i drug [Al'bina Tsybikova - the artist and the friend]. In Vestnik Evrazii, Eurasian Bulletin, 3 (21), 42-106. 
Lotman, Iu. (2005). On the semiosphere. In Sign Systems Studies, 33.1, 205-229.

Lotman, Iu.M. (2001). Semiosfera [Semiosphere]. Saint Petersburg: "Iskusstvo SPb.", 704 p.

Mudraia sila "Baikala" [Wise power of "Baikal”] (2005). In Moi liubimyi gorod. Spets. vyp., posviashch. 339-letiiu g. Ulan-Ude [My favorite city. A special issue on the 339 anniversary of the city of Ulan-Ude], 20.

Politov, A. (2000). Skazanie o zemnykh i nezemnykh nebesnykh devakh [A Legend about terrestrial and unearthly heavenly maidens]. In Buriatia, November 16, 8.

Synduev, E. (2005). Pesennyi iazyk [Song language]. In Pravda Buriatii, Nov. 3, 14.

Vasil'eva, A. (2001). "Chinggis-khan": v ozhidanii chuda [Chinggis-khan: waiting for a miracle]. In Pravda Buriatii, June 8, 12.

Vseburiatskaia assotsiatsiia razvitiia kul'tury vybrala svoego novogo predsedatelia [The All-Buryat Association for development of culture has chosen its chairman] (2016). Buryaad Unen, July 1. Available at https://burunen.ru/site/news?id=11882 (accessed February 1, 2018).

\title{
Художественная культура и этничность: сохраняя современную бурятскую этносферу
}

Д.Д. Амоголонова

Институт монголоведения, буддологии и тибетологии СО РАН

Россия, 670047, Улан-Удэ, ул. Сахьяновой, 6

\begin{abstract}
В статье предлагается новый взгляд на феномен этносферы на материалах постсоветской Бурятии. Хотя этничность в России деполитизируется в течение последних почти двух десятилетий, тем не менее она остается одной из основных социальных идентичностей, проявляясь в настоящее время не в политическом, а в культурном пространстве. Автор полагает, что, утратив политическое содержание и пафос периода этнической мобилизаџии (с кониа 1980-х до 2000 года), идеи этнонационального возрождения и этнической консолидащии нашли выражение и воплощение в художественной культуре. Деятели различных областей художественного творчества - живописи, прозы и поэзии, театра, музыки, кино - находятся в поисках путей и форм, позволяюших успешно связать этнические культурные традиции с современными художественными средствами выражения. При этом сюжеты разнообразны, но соответствуют темам бурятской идеологии: великое прошлое, реальные исторические и фольклорные национальнье герои, духовность и религиозность, спасение этнического
\end{abstract}


языка, сохранение традиционной экономики, поддержание связей с монгольской общиностью.

Ключевые слова: буряты, художественная культура, деполитизаичя, культурная этносфера, историческая память, бурятская идеология, идентичность, культурное наследие.

Исследование выполнено в рамках проекта «Комплексное исследование религиознофилософских, историко-культурных, социально-политических аспектов буддизма в традиционных и современных контекстах России и стран Центральной и Восточной Азии».

Научная специиальность: 24.00.00 - культурология. 